\title{
Evaluation of the Results of Attitudes and Self-Efficacy of Middle School Students in Science Subjects
}

\section{Budiarti Retni S ${ }^{*}$, Kurniawan Dwi Agus ${ }^{2}$, Triani Elza ${ }^{3}$, Perdana Rahmat ${ }^{4}$}

\author{
1,2,34 Faculty of Teaching And Educational Science Universitas Jambi
}

\section{A R T I CLE I N F O}

Article history:

Received July 02, 2021

Revised July 05, 2021

Accepted September 24, 2021

Available online November 25, 2021

Kata Kunci :

Sains, Sikap, Efikasi Diri

Keywords:

Science, Attitude, Self-Efficacy

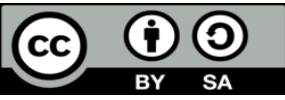

This is an open access article under the $\underline{C C}$ BY-SA license.

Copyright $@ 2021$ by Author. Published by Universitas Pendidikan Ganesha

\begin{abstract}
A B S T R A K
Sikap dan efikasi diri yang baik dalam kepribadian setiap siswa sangat penting dimiliki guna memaksimalkan aktivitas dan hasil belajar setiap siswa. Urgensi penelitian ini sebagai acuan bagi para pendidik dalam melakukan pengajaran untuk mengetahui pengaruh yang signifikan dan berkelanjutan terhadap keberhasilan prestasi belajar siswa pada mata pelajaran IPA dan kinerja siswa terhadap variabel efikasi diri dan sikap dalam belajar. Penelitian ini bertujuan untuk mengetahui perbedaan dan hubungan antara sikap dan efikasi diri siswa pada mata pelajaran IPA. Jenis penelitian ini adalah kuantitatif komparatif. Jumlah responden sebagai sampel adalah 74 siswa. Teknik pengumpulan data menggunakan simple random sampling. Hasil penelitian menggunakan uji $T$ yaitu terdapat perbedaan yang signifikan sikap siswa pada pelajaran IPA baik siswa perempuan maupun laki-laki di kelas VII A dan kelas VII B. Dari hasil uji T efikasi diri terdapat perbedaan efikasi diri siswa pada pelajaran IPA baik siswa maupun siswa laki-laki di kelas VII A dan kelas VII B. Hasil uji korelasi antara sikap dan efikasi diri siswa terhadap mata pelajaran IPA di kelas VII $A$ dan VII $B$ menunjukkan bahwa sikap dan efikasi diri berhubungan. Penelitian ini memiliki keterbatasan diantaranya peneliti hanya mengukur sikap dan efikasi diri siswa kelas VII. Saran bagi peneliti selanjutnya dapat meneliti atau mengukur minat dan motivasi siswa atau membuat generalisasi tentang penelitian ini.
\end{abstract}

\begin{abstract}
A B S T R A C T
Good attitudes and self-efficacy in each student's personality are very important to have in order to maximize the activities and learning outcomes of each student. The urgency of this research as a reference to the educators in conducting teaching to find out the significant and continuous impact on the success of student achievement in science subjects and student performance on the variables of self-efficacy and attitude in learning. This study aims to determine the differences and the relationship between attitudes and self-efficacy of students in science subjects. The type of research is comparative quantitative. The number of respondents as a sample is 74 students. The data collection technique used simple random sampling. The results of the study using the $T$ test, which is a significant difference in student attitudes in science lessons, both female and male students in class VII A and class VII B. From the results of the $T$ test for self-efficacy, there are differences in student self-efficacy in lessons Science both students and male students in class VII A and class VII B. The results of the correlation test between students' attitudes and self-efficacy towards science subjects in class VII A and VII B showed that attitudes and self-efficacy were related. This study has limitations including researchers only measuring the attitudes and self-efficacy of students in class VII. Recommendations for further researchers can research or measure students' interests and motivations or make generalizations about this research.
\end{abstract}

\section{INTRODUCTION}

Education is a means to improve the quality of each student. The purpose of education is for the desired behavior change to occur after students learn, turning potential into advantages and becoming a strategic place to develop social skills (Amrullah et al., 2017; Rohmawati, 2018; Sihombing, 2020). The role of education is very important in human life where educational institutions act as centers of appreciation, development, identity formation and each educational institution has its own teaching goals (Hanifa, 2018; Musanna, 2017; Pambudi et al., 2019). The quality of education is very important because someone who is able to solve problems using scientific concepts obtained in education is basically an effort to improve the quality of human resources (Fakhriyah et al., 2017; Megawati et al., 2019; Usman Fauzan \& Aldila Afriansyah, 2017). So that every student needs to have a scientific attitude. Then at the education level, scientific knowledge and attitudes can be obtained. Scientific attitude is an important part of judgment which is a combination of a number of mental habits or tendencies to react in certain ways to problematic situations (Jufrida, 2019; Mediartika \& Aznam, 2018; Metzger \& Fehr, 2018). Scientific attitude is a very important aspect in simple scientific activities where science educators tend to distinguish two types in the 
discipline of science attitude and scientific attitude and assessment of scientific attitude in the form of nontest assessment (Dewi et al., 2017; Sole \& Anggraeni, 2017; Tretter et al., 2019). Basically there is still uncertainty about which attitude and teaching approach, associating with students' scientific intentions so that it can be used to inspire more students to study science subjects, taken from the many scientific attitudes that must be applied in studying physics (Astalini. et al., 2018; Mujtaba et al., 2018; Nufus et al., 2017). Scientific attitude by students is useful so that students can be consistent in every situation in participating in learning activities, especially in science lessons.

In increasing students' knowledge and developing their scientific attitude, it can be adopted from natural science subjects. Science subject is a school science lesson whose learning process emphasizes more on providing hands-on practice where students are given some instructions on collecting, processing, and analyzing to solve a problem and make the knowledge learned more meaningful (Anisa, 2017; Bellová et al., 2018; Hartina et al., 2020). Science learning in the classroom is an active learning process with the rapid development of science in various aspects demanding a learning method that can prepare students to be able to understand science for that natural science is easier to understand if it uses language that is easy for students to understand (Grobler, 2018; Pamungkas et al., 2017; Utaminingsih et al., 2018). Science subjects are related to how to find out about nature systematically which is also a process of discovery, in such a process it is seen that the performance gap between disadvantaged students and middle-class students is very large and one of the obstacles for educators in elaborating an integrated science learning plan is the background. behind educators who are still in one discipline, namely biology, physics and chemistry (Camasso \& Jagannathan, 2018; Firdaus \& Wilujeng, 2018; Iswatun et al., 2017). In science learning, many students do not like physics lessons which they consider difficult lessons.

Physics is the most basic branch of the natural sciences and deals with how the universe works. Physics learning can develop skills by measuring students' understanding of physics concepts, this has an impact on maintaining the physics identity over time (Siswoyo \& Sunaryo, 2017; Wang et al., 2018; Yao et al., 2020). Physics material is material related to everyday life, so teachers are required to be able to explain concepts in real form for that physics requires a scientific investigation process that can be done by: practicum activities (Astuti et al., 2017; Asy'ari et al., 2019; Darmaji et al., 2019). Physics is a field of study that concerns natural phenomena, and students are required to understand the concepts that exist in these natural phenomena, the opinion of physics mainly consists of the concept of matter, the concept of motion and interaction, the concept of energy and other elements (Dell'Aquila \& Russo, 2021; Liu \& Sun, 2020; Ratnaningdyah, 2017). When studying physics activities, students are required to be able to understand concepts and also be able to find solutions to problems, in understanding concepts sometimes male students do not focus on participating in activities.

This makes gender issues considered to affect student learning success. Of further note is the term gender equality whose primary goal is gender neutral citizenship, in which women are allowed to participate with men as equal citizens, especially in the public sphere, and the fact that no research has yet explored the predictive power of student achievement. based on gender (Josephidou, 2020; Ugwuanyi et al., 2020; Woehrle et al., 2011). Gender equality is like a "holy" expression (term) that is often used by social activists, feminists, politicians, and even almost by state officials (Effendi \& Ratnasari, 2018; Fraile \& Gomez, 2017; Subašić et al., 2018). Gender gaps appear much earlier in science which means Gender has an important impact on students' choice of specialization, that gender has a significant moderating effect on predictive power of motivation and self-efficacy on academic achievement of physics students in favor of male physics students (Cahyanto et al., 2019; Levaillant et al., 2020; Ugwuanyi et al., 2020). From this it can be seen that gender has an effect on self-efficacy in participating in learning, especially science.

In participating in science learning, students who have good self-efficacy will succeed in their learning activities and can complete their tasks smoothly. Self-efficacy provides the basis for human motivation, well-being, and personal achievement (Priska et al., 2020; Sachitra \& Bandara, 2017; Trautner \& Schwinger, 2020). Self-efficacy refers to the perception of an individual's ability to organize and carry out actions to display certain skills Self-efficacy is an individual's assessment of his ability or competence to perform tasks, achieve goals, and produce something, a teacher can facilitate to improve the learning experience of self-efficacy (Hodges, 2018; Kartika, 2021; Zimmerman et al., 1996). The success of implementing a learning model can also be influenced by student characteristics, one of which is selfefficacy (Aharony \& Gazit, 2020; Hasyim \& Eldiana, 2020; Wong et al., 2020). Students have different selfefficacy, this difference is based on the level of confidence and ability of each student. Based on the description above, good attitudes and self-efficacy in each student's personality are very important to have in order to maximize the activities and learning outcomes of each student, so the researchers here aim to find out the comparison of students' attitudes between women and men towards science subjects, knowing the comparison of self -efficacy in female and male students towards science subjects and to determine the relationship between attitudes and self-efficacy in students towards science subjects. 


\section{METHODS}

This type of research uses a quantitative type that produces several findings that can be achieved using some statistical procedures or other means of quantification (measurement). The quantitative approach focuses more on the symptoms or phenomena that have certain characteristics in human life, which are called variables. A quantitative approach to the nature of the relationship between the variables analyzed using an objective theory. Based on the level of explanation, research can be grouped into descriptive, comparative, and associative research. Descriptive research is directed to determine the value of the independent variable (either one or more variables) without making comparisons or connecting one variable to another. Comparative research is directed to determine the comparison between variables by using more than one sample and/or in different time periods. The sample in this study was 74 students from SMPN 2 Muaro Jambi. The sampling technique is purvosive sampling. Purposive sampling is a type of sampling in which a research more a less handpicks case (Stommel \& Willis, 2004). The sampling technique is total sampling. The subjects taken were class VII consisting of 40 women and 34 men.

There are 2 instruments in this study, namely attitudes towards science and self-efficacy. The assessment instrument is one of the most important assessment instruments for attitudes. There are 56 valid question items on this instrument using a Likert scale. The scale consists of 5 points with a score of strongly agreeing is 5 , agreeing is 4 , neutral is 3 , disagreeing is 2 , and strongly disagreeing is 1 . Each statement is representative of each attitude indicator. Focus Due to the attitude questionnaire of students in science subjects using a Likert scale consisting of 5 categories, there are intervals in each category, and the intervals in each category can be seen in the table. The grid of the questionnaire instrument of the students' attitude variables and the indicators used in this study are as shown in Table 1.

Table 1. Grid of Students' Attitude Questionnaire

\begin{tabular}{llll}
\hline \multirow{2}{*}{ Variable } & \multicolumn{1}{c}{ Indicator } & \multicolumn{1}{c}{ No. Statement Items } \\
\cline { 3 - 4 } & & \multicolumn{1}{c}{$\mathbf{( + )}$} & \multicolumn{1}{c}{$(-\mathbf{)}$} \\
\hline \multirow{4}{*}{ Attitudes } & Social Implications of Science & $1,14,27,39$ & $7,20,32,45,53$ \\
& Scientist Normality & $8,21,33,46,54$ & 15,40 \\
& Attitude Towards Science Investigation & 2,41 & $9,22,34,47,55$ \\
& Adopt Scientific Attitude & $3,26,28$ & $10,23,35,48$ \\
& Fun in Learning Science & $4,17,29$ & $11,24,36,42,49,56$ \\
& Interest in Increasing the Time to Study Science & $5,18,30$ & $12,25,37,43,50$ \\
& Interest in a Career in Science & $13,19,26,38,51$ & $6,31,44,52$ \\
\hline & Number of Statements & $\mathbf{2 5}$ & $\mathbf{3 1}$ \\
\hline
\end{tabular}

Furthermore, the grid of the student self-efficacy variable questionnaire instrument and the indicators used in this study are as shown in Table 2.

Table 2. Grid of Self-Efficacy Questionnaire

\begin{tabular}{clc}
\hline Variable & \multicolumn{1}{c}{ Indicator } & No. Statement Items \\
\hline & Task Difficulty Level & $1,2,3$ \\
Self-efficacy of & Take experience not as an obstacle & $19,20,21,22,23$ \\
students in & Using deep experience as a basis for increasing confidence & $24,25,26,27,28$ \\
science subjects & Individual Expectations of Ability & $13,14,15,16,17,18$ \\
& Taking Experience Not as an Obstacle & $19,20,21,22,23$ \\
& Making Inner Experience The Basis To Increase Confidence & $24,25,26,27,28$ \\
\hline \multicolumn{2}{c}{ Number of Statements } & $\mathbf{2 8}$ \\
\hline
\end{tabular}

From this data, data analysis is then carried out, namely data coding, filtering appropriate data and analyzing the data. In data analysis using descriptive and inferential statistics. Descriptive statistics are used to explain a series of information that has been collected (Putri et al., 2020), consisting of percentage, frequency, mean, median, min, max. Then the data analysis was carried out using inferential statistics, the first was the assumption test, namely the normality test where The results of the normality test are seen from: Histogram, Kolmogorov Smirnov test: significant value, if it is more than $5 \%$, is said to be normally distributed (Setiaman, 2019). Continue the homogeneity test where The data that was tested was said to be homogeneous based on its significance value. The significance value (p) 0.05 indicates that the data group comes from a population that has the same variance (homogeneous) The significance value $(\mathrm{p})<0.05$ 
indicates that each data group comes from a population with different variances (not homogeneous) (Haryanti, 2021). After that, a linearity test is carried out where the decision-making techniques in the linearity test are as follows. a. By looking at the significance value. If Deviation from linearity Sig $>0.05$ then there is a significant linear relationship between the independent variable and the dependent variable. If Deviation from linearity Sig 0.05 then there is no significant linear relationship between the independent variable and the dependent variable (Marzuki et al., 2020). After obtaining the results that meet the requirements of the assumption test, then further tests can be carried out, namely hypothesis testing which consists of the T-test type independent sample t-test where The basis for decision making is if the value of sig. (2-tailed ) $<0.05$ then there is no significant difference, and if the value of sig. (2-tailed ) $>0.05$ then there is a significant difference and correlation test Here the researcher uses the one based on the Significance Value of Sig. (2-tailed): where If the value of Sig. $(2$-tailed) $<0.05$ then there is a correlation between the variables connected. There are three ways that we can use as a guideline or basis for making decisions in this Pearson bivariate correlation analysis, namely first by looking at the significance value of Sig. (2-tailed). Second, compare the calculated $r$ value (Pearson Correlations) with the $r$ value of the product moment table. The third is to look at the asterisk ${ }^{*}$ ) contained in the output of the SPSS program. In the correlation test here the researcher uses the one based on the Significance Value of Sig. (2-tailed): where If the value of Sig. (2-tailed) $<0.05$ then there is a correlation between the variables connected. On the other hand, if the value of Sig. ( 2 tailed) $>0.05$ then there is no correlation.

\section{RESULT AND DISCUSSION}

\section{Results}

The data that has been obtained from class VII A and VII B at SMPN 2 Muaro Jambi using the assumption test. The classical assumption test also does not need to be carried out for linear regression analysis which aims to calculate the value of certain variables. In this study, there will be 3 types of assumption tests, namely normality test, homogeneity test and linearity test. Here are the results of the tests that have been tested.

\section{Normality Test}

Normal distribution test or normality test is a test to measure whether our data has a normal distribution so that it can be used in parametric statistics (inferential statistics). The purpose of the normality test is to find out whether the empirical data we get from the field is in accordance with the theoretical distribution. The results of the normality test for attitudes and self-efficacy in grades VII A and VII B of SMPN 2 Muaro Jambi is presented in Table 3.

Table 3. Normality Test Results

\begin{tabular}{cccccccc}
\hline \multirow{2}{*}{ Variable } & \multirow{2}{*}{ Class } & \multicolumn{3}{c}{ Kolmogorov-Smirnov } & \multicolumn{3}{c}{ Shapiro-Wilk } \\
\cline { 3 - 8 } & & Statistic & Df & Sig. & Statistic & Df & Sig. \\
\hline \multirow{2}{*}{ Attitudes } & VII_A & 0.129 & 37 & 0.122 & 0.922 & 37 & 0.012 \\
Self- & VII_B & 0.064 & 37 & 0.200 & 0.987 & 37 & 0.939 \\
Efficacy & VII_A & 0.144 & 37 & 0.051 & 0.954 & 37 & 0.130 \\
& VII_B & 0.121 & 37 & 0.194 & 0.940 & 37 & 0.045 \\
\hline
\end{tabular}

Based on the results of Table 3, to find out how to obtain a normality test with the KolmogorovSmoniv test, a significance value of $>$ from 0.05 , then the data can be obtained normally distributed. Based on the results of Table 3, for Self-Efficacy, the normality test is obtained with the Kolmogorov-Smoniv test with a significance value of $>0.05$, so it can be said that the key is normally distributed.

\section{Homogeneity Test}

Homogeneity test is a test to determine whether the two groups of data to be processed have the same variance. Because one of the requirements for analyzing parametric statistical tests for hypotheses, if the type is comparison or comparison, it must have homogeneous data. The results of the homogeneity test of class VII A and VII B data at SMPN 2 Muaro Jambi is presented in Table 4. Based on the results in Table 4, it can be ascertained that the data has a sig value of 0.05 , which means it shows a group of data that comes from a population that has the same variance (homogeneous). 
Table 4. Homogeneity Test Results

\begin{tabular}{lll}
\hline Variable & Kelas & Sig. \\
\hline Attitudes & VII A & 0.114 \\
& VII B & \\
Self-efficacy & VII A & 0.809 \\
& VII B & \\
\hline
\end{tabular}

\section{Linearity Test}

The assumption of linearity states that there is a linear relationship between research variables or variables of interest. To maintain the assumption of linearity, the first step is to select variables that are theoretically linearly related. The results of the linearity test between attitudes and self-efficacy in grades VII A and VII B at SMPN 2 Muaro Jambi is presented in Table 5.

Table 5. Linearity Test Results

\begin{tabular}{ccc}
\hline Variable & Group & Significance \\
\hline Attitude $^{*}$ Self-Efficacy & VII A & 0.087 \\
& VII B & 0.112 \\
\hline
\end{tabular}

Based on Table 5, the results of class VII A linearity test are obtained, namely the value of sig. 0.087 where $0.087>0.05$ then there is a relationship between attitudes and self-efficacy of students in class VII A, the result of class VII B linearity test is the value of sig. 0.112 where $0.112>0.05$ then there is a relationship between attitudes and self-efficacy of students in class VII A. After testing the next assumption and getting significant results, then you can test the hypothesis.

\section{Hypothesis Test}

Hypothesis test is a procedure that is carried out and aims to decide whether to accept or reject the hypothesis about population parameters. In this study, two hypothesis tests will be conducted, namely the $\mathrm{T}$ test and the correlation test. Hypothesis test $\mathrm{t}$-test is a hypothesis used to determine whether there is a difference in the average of the samples taken so that the t-test is also known as the average test. The results of the $\mathrm{T}$ test from the data obtained using the independent sample t-Test is presented in Table 6.

Table 6. Independent T-Test Results

\begin{tabular}{|c|c|c|c|c|}
\hline Class & Variable & Student & $\mathbf{N}$ & Sig. (2-tailed) \\
\hline \multirow[t]{4}{*}{ VII A } & \multirow[t]{2}{*}{ Attitude } & Female & 20 & \multirow[t]{2}{*}{0.034} \\
\hline & & Male & 17 & \\
\hline & \multirow[t]{2}{*}{ Self-efficacy } & Female & 20 & \multirow{2}{*}{0.045} \\
\hline & & Male & 17 & \\
\hline \multirow[t]{4}{*}{ VII B } & Attitude & Female & 20 & \multirow[b]{2}{*}{0.045} \\
\hline & \multirow{3}{*}{ Self-efficacy } & Male & 17 & \\
\hline & & Female & 20 & \multirow{2}{*}{0.023} \\
\hline & & Male & 17 & \\
\hline
\end{tabular}

Based on the Table 6, the results of the T-test of students' attitudes in class VII A obtained the value of sig. for attitude that is 0.034 where the result is $<0.05$, it means that the attitude of class VII A students between boys and girls has differences, as well as for student self-efficacy, sig. (2-tailed) $0.045<0.05$ means that the self-efficacy of students in class VII A between boys and girls has a difference. Then the results of the T-test of students' attitudes in class VII B obtained a sig value. (2-tailed) 0.045 which $<0.05$ means that the attitudes of class VII B students between boys and girls have differences, as well as for students' selfefficacy, sig scores are obtained. (2-tailed) $0.045<0.05$ means that the self-efficacy of students in class VII $B$ between boys and girls has a difference.

\section{Correlation Test}

Correlation test is a statistical analysis to see the relationship between two variables with numerical data. The results from the correlation test from the data is presented in Table 7. 
Table7. Correlation Test Results

\begin{tabular}{lllll}
\hline Class & Variable & N & Pearson Correlation & Sig. (2-tailed) \\
\hline VII A & Attitude & 37 & 0.668 & 0.046 \\
VII B & Self efficacy & 37 & 0.648 & 0.035 \\
\hline
\end{tabular}

Based on the results in Table 7, obtained the value of Sig. (2-tailed) in class VII B students is 0.046 where the value is $<0.05$ meaning that there is a relationship between correlated variables. Next is the correlation test between attitudes and self-efficacy in class VII B students, based on the table the results obtained are Sig. (2-tailed) is 0.035 where the value $<0.05$ means that there is a relationship between correlated variables. It can be concluded that the data obtained are significant, have differences, and are related between correlated variables.

\section{Discussion}

Analysis of the assumption test data used in this study are: Normality test, linearity test and homogeneity test. The assumption test on this data was carried out with the help of IBM SPSS Statistic 26. The requirements for data analysis using parametric statistics were that the data obtained were normally distributed and homogeneous, so before the ANOVA test was carried out, normality and homogeneity tests were carried out. Normality test was used to determine whether the samples taken were normally distributed. population or not. This normality test uses the Kolmogorov-Smirnov formula (Qomariyah, 2019). The results of the normality test in class VII A and VII B obtained a normality test with the Kolmogorov-Smirnov significance value $>$ from 0.05 , it can be concluded that the data is normally distributed. The results of the homogeneity test obtained from the attitudes and self-efficacy of students towards science subjects for class VII A and VII B obtained a significance value of $>0.05$ so it can be concluded that the two variables are homogeneous. The results of class VII A linearity test are obtained, namely the value of sig. 0.087 where $0.087>0.05$ then there is a relationship between attitudes and selfefficacy of students in class VII A, the result of class VII B linearity test is the value of sig. 0.112 where 0.112 $>0.05$ then there is a relationship between attitudes and self-efficacy of students in class VII B.

After testing the assumptions, the data results are homogeneous, significant and have a linear relationship, then the data can be continued for hypothesis testing, namely $\mathrm{T}$ test and correlation test. Analysis of test data using t-test (Independent Sample T-Test) where the independent sample t-test was conducted to compare the achievements of the two groups and the data will be processed using T-test; This study is intended to determine the effect of using discovery and inquiry learning models on learning outcomes (Istuningsih et al., 2018; Jony, 2020; Wulandari \& Mustadi, 2019). The results of the T-test of students' attitudes in class VII A obtained the value of sig. for attitude that is 0.034 where the result is $<0.05$, it means that the attitude of class VII A students between boys and girls has differences, as well as for student self-efficacy, sig. (2-tailed) $0.045<0.05$ means that the self-efficacy of students in class VII A between boys and girls has a difference. Then the results of the T-test of students' attitudes in class VII B obtained a sig value. (2-tailed) 0.045 which $<0.05$ means that the attitudes of class VII B students between boys and girls have differences, as well as for students' self-efficacy, sig scores are obtained. (2-tailed) 0.045 $<0.05$ means that the self-efficacy of students in class VII B between boys and girls has a difference.

The results of the correlation test are to see the relationship between the variables being tested. Pearson correlation was used to test the correlation and strength of the relationship between each independent variable and the dependent variable (Kowang et al., 2021; Ndongfack, 2021; Tambunan et al., 2021). Based on the results, obtained the value of Sig. (2-tailed) in class VII B students is 0.046 where the value is $<0.05$ meaning that there is a relationship between correlated variables. Next is the correlation test between attitudes and self-efficacy in class VII B students, based on the table the results obtained are Sig. (2-tailed) is 0.035 where the value $<0.05$ means that there is a relationship between correlated variables.

This research is in line with previous research on student attitudes, discussing student attitudes towards science (Kurniawan et al., 2019). The limitation of this research is that it only uses three indicators discussed, namely attitudes towards research in the field of science, adoption of scientific attitudes, and interest in a career in science. the similarity between previous and current research is in the indicators of interest in a career in science. The difference is also in the indicators used in this study using four indicators and the sample used, namely in previous studies using a large sample but not detailing the students at what level, while in this study the researchers used samples from class VII A and VII B at the junior high school level in Muaro Jambi. Then in other research also discusses the comparison of student attitudes towards science with 3 indicators, namely adopting scientific attitudes, pleasure in learning science, and interest in increasing science learning time. in previous studies only discussed one variable, namely only measuring student attitudes, and also the indicators used were only three attitude indicators (Maison et al., 2020). So 
the researchers here carry out generalizations or updates, namely analyzing in order to find out students' attitudes in learning science with different indicators from previous research and using a clear sample level. So that this research can complement the previous research.

This research is also in line with previous research which examined the role of self-efficacy and positive thinking skills on mathematical problem-solving abilities, the limitations of this study were the samples used were high school students and also only examined the effect of self-efficacy on solving problems. math problem (Yuliyani et al., 2017). The difference with the current study is that this study links self-efficacy and positive thinking, and this previous study also did not discuss the indicator self-efficacy variables. So here the researchers conducted a research update, namely by conducting research on the selfefficacy of junior high school students in Muaro Jambi, an indicator in science subjects where science is one of the important sciences for each individual to learn, and in this study a different self-efficacy test was carried out for each individual student and the relationship between self-efficacy variables with student attitudes in learning science.

In this study, the aim of this study was to find out the comparison of students' attitudes between women and men towards science subjects, the comparison of students' self-efficacy between women and men towards science subjects and to find out the relationship between attitudes and self-efficacy in students. In this study, it examines attitudes with indicators of the social implications of science, namely how students are able to learn independently by being active in the classroom and not considering science lessons as difficult lessons, pleasure in learning science where on this indicator students feel happy (like ) or not in taking science lessons, for that the role of the teacher is very important to be able to foster a sense of love in students in science lessons so that students have a high curiosity in science lessons. learning science, where if students already have a sense of pleasure (likes) then they will have the drive to study longer, and interest in a career in science where this indicator is defined for students who have aspirations to become science scientists or are involved in the world of science a is something that is exciting and interesting for that this indicator is the beginning to achieve work according to the abilities and interests of students. Then self-efficacy with an indicator of the level of task difficulty where each student has confidence in their respective tasks if the student has high self-efficacy or confidence then he will do the task even though the task is difficult, consider experience not as an obstacle where In this indicator, students believe that early failure is progress and can rise and survive with various obstacles, and make experience in as a basis for increasing confidence in this indicator, students have confidence that experience will add insight and grow new businesses to move forward in the future. This is related to student development courses where in these subjects' students must be able to understand, analyze, and evaluate the stages of student development both psychologically, psychomotor, and their implications in the implementation and administration of education.

This article has limitations including researchers only measuring the attitudes and self-efficacy (self-efficacy) of students in class VII. In the attitude research, only 4 indicators were used, namely the social implications of science, pleasure in learning science, interest in increasing science learning time, and interest in a career in science. Then the indicators used for self-efficacy are the level of task difficulty, consider experience not as an obstacle, and make internal experience as a basis for increasing confidence. This research needs to be done to find out the students' feelings, attitudes, and self-confidence in participating in science lessons at the junior high school level. In this research article, it has not measured the interest, motivation of students in participating in science learning. So it is advisable to research or measure the interests and motivation of students.

\section{CONCLUSION}

From the results of the T test on students' self-efficacy for subjects In science, it can be concluded that there are differences in students' self-efficacy towards science subjects, both female and male students in class VII A and class VII B. Based on the results of the correlation test between attitudes and students' self-efficacy towards science subjects in class VII A, it can be concluded that there is a relationship between attitudes and students' self-efficacy towards science subjects, both female students and male students in class VII A and in class VII B, it was obtained that there was a correlation between variables that were correlated. Students' attitudes and self-efficacy towards science subjects are important to study because students' attitudes and self-efficacy have a significant and ongoing influence on success, improve student learning outcomes, and affect student performance. This article has limitations including researchers only measuring the attitudes and self-efficacy (self-efficacy) of students in class VII. Recommendations for future readers (further researchers) can research or measure students' interests and motivations or make generalizations about this research. 


\section{REFERENCES}

Aharony, N., \& Gazit, T. (2020). Students' information literacy self-efficacy: An exploratory study. Journal of Librarianship and Information Science, 52(1), 224-236. https://doi.org/10.1177/0961000618790312.

Amrullah, A., Hadisaputo, S., \& Supardi, K. I. (2017). Pengembangan Modul Chemireligiousa Terintegrasi Pendidikan Karakter Bervisi Sets. Jurnal Inovasi Pendidikan Kimia, 11(1), 1872-1883. https://doi.org/10.15294/jipk.v11i1.9715.

Anisa, A. (2017). Meningkatkan Keterampilan Berpikir Kritis Peserta Didik Melalui Pembelajaran IPA Berbasis Potensi Lokal Jepara. Jurnal Inovasi Pendidikan IPA, 3(1), 1-11. https://doi.org/10.21831/jipi.v3i1.8607.

Astalini., Kurniawan, Dwi. A., S., \& Umaryanti. (2018). Sikap Siswa Terhadap Pelajaran Fisika Di SMAN Kabupaten Batanghari. Jurnal Ilmu Pendidikan Fisika, 3(2), 59-64. https://doi.org/10.26737/jipf.v3i2.694.

Astuti, I. A. D., Sumarni, R. A., \& Saraswati, D. L. (2017). Pengembangan Media Pembelajaran Fisika Mobile Learning berbasis Android. Jurnal Penelitian Dan Pengembangan Pendidikan Fisika, 3(1), 57-62.

Asy'ari, M., Hidayat, S., \& Muhali, M. (2019). Validitas dan efektivitas prototipe buku ajar fisika dasar reflektif-integratif berbasis problem solving untuk meningkatkan pengetahuan metakognisi Validity and effectiveness of reflective-integrative basic physics textbook prototype based on problem solv. Jurnal Inovasi Pendidikan IPA, 5(2), 205-215. https://doi.org/10.21831/jipi.v5i2.27089.

Bellová, R., Melicherčíková, D., \& Tomčík, P. (2018). Possible reasons for low scientific literacy of Slovak students in some natural science subjects. Research in Science and Technological Education, 36(2), 226-242. https://doi.org/10.1080/02635143.2017.1367656.

Cahyanto, M. A. S., Ashadi, A., \& Saputro, S. (2019). An Analysis of Gender Difference on Students' Misconceptions in Learning the Material Classification and Its Changes. Jurnal Inovasi Pendidikan IPA, 5(2), 157-167. https://doi.org/10.21831/jipi.v5i2.26613.

Camasso, M. J., \& Jagannathan, R. (2018). Nurture thru Nature: Creating natural science identities in populations of disadvantaged children through community education partnership. The Journal of Environmental Education, 49(1), 30-42. https://doi.org/10.1080/00958964.2017.1357524.

Darmaji, D., Kurniawan, D. A., \& Irdianti, I. (2019). Physics education students' science process skills. International Journal of Evaluation and Research in Education, 8(2), 293-298. https://doi.org/10.11591/ijere.v8i2.28646.

Dell'Aquila, D., \& Russo, M. (2021). Automatic classification of nuclear physics data via a Constrained Evolutionary Clustering approach. Computer Physics Communications, 259, 107667. https://doi.org/10.1016/j.cpc.2020.107667.

Dewi, V. P., Doyan, A., \& Soeprianto, H. (2017). Pengaruh Model Penemuan Terbimbing Terhadap Keterampilan Proses Sains Ditinjau Dari Sikap Ilmiah Pada Pembelajaran Ipa. Jurnal Penelitian Pendidikan IPA, 3(1). https://doi.org/10.29303/jppipa.v3i1.102.

Effendi, P., \& Ratnasari, D. (2018). Kesetaraan Gender Dalam Prespektif Undang-Undang Nomor 13 Tahun 2003 Tentang Ketenagakerjaan. Jurnal Pro Hukum: Jurnal Penelitian Bidang Hukum Universitas Gresik, 7(2), 1-8. http://journal.unigres.ac.id/index.php/JurnalProHukum/article/view/701.

Fakhriyah, F., Masfuah, S., Roysa, M., Rusilowati, A., \& Rahayu, E. S. (2017). Student's science literacy in the aspect of content science? Jurnal Pendidikan IPA Indonesia, 6(1), 81-87. https://doi.org/10.15294/jpii.v6i1.7245.

Firdaus, M., \& Wilujeng, I. (2018). Pengembangan LKPD inkuiri terbimbing untuk meningkatkan keterampilan berpikir kritis dan hasil belajar peserta didik. Jurnal Inovasi Pendidikan IPA, 4(1), 2640. https://doi.org/10.21831/jipi.v4i1.5574.

Fraile, M., \& Gomez, R. (2017). Bridging the enduring gender gap in political interest in Europe: The relevance of promoting gender equality. European Journal of Political Research, 56(3), 601-618. https://doi.org/10.1111/1475-6765.12200.

Grobler, R. (2018). Students' Perceptions of Code-Switching in Natural Sciences Classrooms: A South African $\begin{array}{llll}\text { Perspective. Africa } & \text { Education }\end{array}$ https://doi.org/10.1080/18146627.2016.1224593.

Hanifa, R. (2018). Factors generating anxiety when learning EFL speaking skills. Studies in English Language and Education, 5(2), 230-239. https://doi.org/10.24815/siele.v5i2.10932.

Hartina, L., Rosidin, U., \& Suyatna, A. (2020). Pengaruh Penerapan Instrumen Performance Assessment pada Pembelajaran IPA Berbasis Laboratorium Real terhadap Hasil Belajar Siswa. Jurnal Penelitian Pendidikan IPA, 6(1), 25-31. https://doi.org/10.29303/jppipa.v6i1.299. 
Haryanti, S. (2021). Statistika Dasar untuk Penelitian Jilid 1 dengan Aplikasi SPSS. Media Sains Indonesia.

Hasyim, M., \& Eldiana, N. F. (2020). Eksperimentasi model PBL dan PjBL berbasis schoology terhadap pemecahan masalah matematika ditinjau dari self-efficacy. JP2M (Jurnal Pendidikan Dan Pembelajaran Matematika), 6(2), 87. https://doi.org/10.29100/jp2m.v6i2.1751.

Hodges, C. B. (2018). Self-Efficacy in Instructional Technology Contexts. Springer. https://doi.org/10.1007/978-3-319-99858-9.

Istuningsih, W., Baedhowi, B., \& Bayu Sangka, K. (2018). The Effectiveness of Scientific Approach Using EModule Based on Learning Cycle 7E to Improve Students' Learning Outcome. International Journal of Educational Research Review, 3(3), 75-85. https://doi.org/10.24331/ijere.449313.

Iswatun, I., Mosik, M., \& Subali, B. (2017). Penerapan Model Pembelajaran Inkuiri Terbimbing Untuk Meningkatkan KPS dan Hasil Belajar Siswa SMP Kelas VIII. Jurnal Inovasi Pendidikan IPA, 3(2). https://doi.org/10.21831/jipi.v3i2.14871.

Jony, M. S. (2020). Exploring the Effectiveness of Cooperative Learning at Secondary Level in Bangladesh. International Journal of Educational Research Review, 5(1), 93-99. https://doi.org/10.24331/ijere.669388.

Josephidou, J. (2020). A gendered contribution to play? Perceptions of Early Childhood Education and Care (ECEC) practitioners in England on how their gender influences their approaches to play. Early Years, 40(1), 95-108. https://doi.org/10.1080/09575146.2019.1655713.

Jufrida. (2019). Students' attitude and motivation in mathematical physics. International Journal of Evaluation and Research in Education (IJERE), 8(3), 401-408. https://doi.org/10.11591/ijere.v8i3.20253.

Kartika, K. (2021). Keperawatan Bencana. Deepublish.

Kowang, T. O., Apandi, S. Z. B. A., Hee, O. C., Fei, G. C., Saadon, M. S. I., \& Othman, M. R. (2021). Undergraduates entrepreneurial intention: Holistic determinants matter. International Journal of Evaluation and Research in Education, 10(1), 57-64. https://doi.org/10.11591/ijere.v10i1.20733.

Kurniawan, D. A., Astalini, A., Darmaji, D., \& Melsayanti, R. (2019). Students' Attitude towards Natural Sciences. International Journal of Evaluation and Research in Education, 8(3), 455-460. https: //doi.org/10.11591/ijere.v8i3.16395.

Levaillant, M., Levaillant, L., Lerolle, N., Vallet, B., \& Hamel-Broza, J. F. (2020). Factors influencing medical students' choice of specialization: A gender based systematic review. EClinicalMedicine, 28. https://doi.org/10.1016/j.eclinm.2020.100589.

Liu, T., \& Sun, H. (2020). Key Competencies of Physics Teachers. Higher Education Studies, 11(1), 28. https: //doi.org/10.5539/hes.v11n1p28.

Maison, M., Haryanto, H., Ernawati, M. D. W., Ningsih, Y., Jannah, N., Puspitasari, T. O., \& Putra, D. S. (2020). Comparison of student attitudes towards natural sciences. International Journal of Evaluation and Research in Education, 9(1), 54-61. https://doi.org/10.11591/ijere.v9i1.20394.

Marzuki, A., Armereo, C., \& Rahayu, P. F. (2020). Praktikum Statistik. Ahli Media Press.

Mediartika, N., \& Aznam, N. (2018). Pengembangan Instrumen Penilaian Portofolio Berbasis Multiple Intelligence untuk Mengukur Kemampuan Berpikir Kritis dan Sikap Ilmiah. Jurnal Inovasi Pendidikan IPA, 4(1), 52-63. https://doi.org/10.21831/jipi.v4i1.9973.

Megawati, M., Wardani, A. K., \& Hartatiana, H. (2019). Kemampuan Berpikir Tingkat Tinggi Siswa Smp Dalam Menyelesaikan Soal Matematika Model Pisa. Jurnal Pendidikan Matematika, 14(1), 15-24. https://doi.org/10.22342/jpm.14.1.6815.15-24.

Metzger, B. A., \& Fehr, R. R. (2018). Measuring Financial Risk Attitude: How to Apply Both Regulatory and Scientific Criteria to Ensure Suitability. Journal of Behavioral Finance, 19(2), 221-234. https: //doi.org/10.1080/15427560.2017.1376331.

Mujtaba, T., Sheldrake, R., Reiss, M. J., \& Simon, S. (2018). Students' science attitudes, beliefs, and context: associations with science and chemistry aspirations. International Journal of Science Education, 40(6), 644-667. https://doi.org/10.1080/09500693.2018.1433896.

Musanna, A. (2017). Indigenisasi Pendidikan: Rasionalitas Revitalisasi Praksis Pendidikan Ki Hadjar Dewantara. Jurnal Pendidikan Dan Kebudayaan, 2(1), 117-133. https: //core.ac.uk/download/pdf/322566056.pdf.

Ndongfack, M. N. (2021). Towards a Resilient Model of Education: Factors that foster the use of e-Learning Among Primary School Teachers in Cameroon. International Journal of Educational Research Review, 6(3), 208-217. https://doi.org/10.24331/ijere.895391.

Nufus, S. H., Gani, A., \& Suhendrayatna. (2017). Pengembangan Instrumen Penilaian Sikap Berbasis Kurikulum 2013 Pada Pembelajaran Kimia SMA. Jurnal Pendidikan Sains Indonesia, 05(01), 44-51. http://202.4.186.66/JPSI/article/view/8406. 
Pambudi, M. I., Winarno, M., \& Dwiyogo, W. D. (2019). Perencanaan dan Pelaksanaan Pembelajaran Pendidikan Jasmani Olahraga Kesehatan. Jurnal Pendidikan Olahraga, Universitas Negeri Malang, 4(1), 110-116.

Pamungkas, A., Subali, B., \& Linuwih, S. (2017). Implementasi model pembelajaran IPA berbasis kearifan lokal untuk meningkatkan kreativitas dan hasil belajar siswa. Jurnal Inovasi Pendidikan IPA, 3(2), 118. https://doi.org/10.21831/jipi.v3i2.14562.

Priska, J., Rahmawati, E., \& Utomo, S. (2020). Pengaruh Self Efficacy, Motivasi Dan Kepuasan Kerja Terhadap Kinerja Karyawan PT. PLN Puruk Cahu Kabupaten Murung Raya. Jurnal Bisnis Dan Pembangunan, 9(1), 83-98. https://doi.org/10.20527/jbp.v9i1.8696.

Putri, R. I. I., Araiku, J., \& Sari, N. (2020). Statistik Deskriptif. bENING MEDIA.

Qomariyah, S. N. (2019). Effect of Problem Based Learning Learning Model to Improve Student Learning Outcomes. International Journal of Educational Research Review, 4(2), 217-222. https://doi.org/10.24331/ijere.518056.

Ratnaningdyah, D. (2017). Peningkatan K Emampuan P Emecahan M Asalah M Atematis S Iswa K Elas Vi M Elalui M Odel P Embelajaran K Ontekstual P Ada M Ateri. Jurnal Ilmu Pendidikan Fisika, 2(1), 1-3.

Rohmawati, A. (2018). Children's Social Skills Stimulation Viewed From Early Childhood Education Unit in Indonesia. International Journal of Educational Research Review, 3(3), 69-73. https://doi.org/10.24331/ijere.443852.

Sachitra, V., \& Bandara, U. (2017). Measuring the Academic Self-Efficacy of Undergraduates: The Role of Gender and Academic Year Experience. World Academy of Science, Engineering and Technology, International Journal of Social, Behavioral, Educational, Economic, Business and Industrial Engineering, 11(11), 2443-2448.

Setiaman, S. (2019). Analisis korelasi dan regresi linear sederhana. PPNI.

Sihombing, R. (2020). Penerapan Model Pembelajaran Kooperatif Giving Question and Getting Answer Terhadap Aktivitas Belajar Dan Hasil Belajar Siswa Pada Materi Menerapkan Prosedur Kegiatan Rapat. Jurnal Teknologi Pendidikan (JTP), 13(1), 57. https://doi.org/10.24114/jtp.v13i1.18000.

Siswoyo, \& Sunaryo. (2017). High Order Thinking Skills: Analisis Soal dan Implementasinya dalam Pembelajaran Fisika di Sekolah Menengah Atas. Jurnal Penelitian \& Pengembangan Pendidikan Fisika, 3(1), 11-20. https://doi.org/10.21009/1.03102.

Sole, F. B., \& Anggraeni, D. M. (2017). Pengembangan Instrumen Penilaian Sikap Ilmiah Sains Siswa Sekolah Dasar (SD) Berbasis Pendidikan Karakter. Jurnal Penelitian Pendidikan IPA, 3(2), 99-105. https://doi.org/10.29303/jppipa.v3i2.111.

Stommel, M., \& Willis, C. (2004). Clinical Research, Concepts and Principles for Advanced Practice Nurses. Lippincott Williams.

Subašić, E., Hardacre, S., Elton, B., Branscombe, N. R., Ryan, M. K., \& Reynolds, K. J. (2018). "We for She": Mobilising men and women to act in solidarity for gender equality. Group Processes and Intergroup Relations, 21(5), 707-724. https://doi.org/10.1177/1368430218763272.

Tambunan, H., Sinaga, B., \& Widada, W. (2021). Analysis of teacher performance to build student interest and motivation towards mathematics achievement. International Journal of Evaluation and Research in Education, 10(1), 42-47. https://doi.org/10.11591/ijere.v10i1.20711.

Trautner, M., \& Schwinger, M. (2020). Integrating the concepts self-efficacy and motivation regulation: How do self-efficacy beliefs for motivation regulation influence self-regulatory success? Learning and Individual Differences, 80(May). https://doi.org/10.1016/j.lindif.2020.101890.

Tretter, T. R., Ardasheva, Y., Morrison, J. A., \& Karin Roo, A. (2019). Strengthening science attitudes for newcomer middle school english learners: visually enriched integrated science and language instruction. International Journal of Science Education, 41(8), 1015-1037. https://doi.org/10.1080/09500693.2019.1585993.

Ugwuanyi, C. S., Okeke, C. I. O., \& Ageda, T. A. (2020). Psychological predictors of physics learners' achievement: The moderating influence of gender. Cypriot Journal of Educational Sciences, 15(4), 834-842. https://doi.org/10.18844/cjes.v15i4.4635.

Usman Fauzan, A., \& Aldila Afriansyah, E. (2017). Kemampuan Pemahaman Matematis Siswa Melalui Model Pembelajaran Auditory Intellectualy Repetition dan Problem Based Learning. Jurnal Pendidikan Matematika, 11(1), 68-78.

Utaminingsih, R., Rahayu, A., \& Andini, W. (2018). Pengembangan RPP IPA sekolah dasar berbasis problembased learning untuk siswa learning disabilities. Jurnal Inovasi Pendidikan IPA, 4(2), 191-202. https://doi.org/10.21831/jipi.v4i2.21401.

Wang, J., Hazari, Z., Cass, C., \& Lock, R. (2018). Episodic memories and the longitudinal impact of high school physics on female students' physics identity. International Journal of Science Education, 40(13), 1543-1566. https://doi.org/10.1080/09500693.2018.1486522. 
Woehrle, H., Graml, A., \& Weinreich, G. (2011). Age-and gender-dependent adherence with continuous positive airway pressure therapy. Sleep Medicine, 12(10), 1034-1036. https://doi.org/10.1016/j.sleep.2011.05.008.

Wong, W. C. W., Sun, W. H., Chia, S. M. C., Tucker, J. D., Mak, W. P. H., Song, L., Choi, K. W. Y., Lau, S. T. H., \& Wan, E. Y. F. (2020). Effectiveness of a Peer-Led Web-Based Intervention to Improve General SelfEfficacy in Using Dating Apps among Young Adults: Randomized Clustered Trial. Journal of Medical Internet Research, 22(10). https://doi.org/10.2196/16378.

Wulandari, D. G. R., \& Mustadi, A. (2019). Comparison of Discovery and Inquiry Model: Which Model is More Effective in Natural Science (IPA) Learning? International Journal of Educational Research Review, 4(Special Issue), 711-718. https://doi.org/10.24331/ijere.628710.

Yao, G., Black, K., Ramsdell, M., \& Skufca, J. (2020). Coordinated Math-Physics Assessment as an Alternative $\begin{array}{llll}\text { Pathway in } & \text { Early }\end{array}$ https://doi.org/10.1080/10511970.2018.1506533.

Yuliyani, R., Handayani, S. D., \& Somawati. (2017). Peran efikasi diri (self-efficacy) dan kemampuan berpikir positif terhadap kemampuan pemecahan masalah matematika. Formatif: Jurnal Ilmiah Pendidikan MIPA, 7(2), 130-143. https://doi.org/10.30998/formatif.v7i2.2228.

Zimmerman, B. J., Bonner, S., \& Kovach, R. (1996). Developing self-regulated learners: Beyond achievement to self-efficacy. In Focus on Exceptional Children. American Psychological Association. 